\title{
Assess the Effect of Pruning and Plant Growth Regulators on Yield and Quality of Ber Fruit
}

\author{
Sneha Singh ${ }^{1 *}$, Bhanu Pratap ${ }^{1}$, Sachi Gupta ${ }^{1}$, Dheeraj Yadav ${ }^{1}$, Abhinav Kumar ${ }^{1}$, \\ Swosti Debapriya ${ }^{1}$, Behera $^{1}$ and Madhusoodan Singh $^{2}$ \\ ${ }^{1}$ Department of Horticulture, ${ }^{2}$ Department of Economics, \\ N.D. University of Agriculture \& Technology Kumarganj Faizabad-224229, India \\ *Corresponding author
}

\begin{tabular}{|l|}
\hline Ke y w o r d s \\
Ber, Pruning \\
Intensity, Yield, \\
Quality \\
\hline Article Info \\
\hline $\begin{array}{l}\text { Accepted: } \\
\text { 07 December } 2018 \\
\text { Available Online: } \\
\text { 10 January } 2019\end{array}$ \\
\hline
\end{tabular}

\section{Introduction}

Ber (Zizyphus mauritiana Lamk.) is an ancient
fruit tree of India and China. It belongs to
family Rhamnaceae and is probably native to
India. Ber is also known as Chinese date or

Ber (Zizyphus mauritiana Lamk.) is an ancient
fruit tree of India and China. It belongs to
family Rhamnaceae and is probably native to
India. Ber is also known as Chinese date or

Ber (Zizyphus mauritiana Lamk.) is an ancient
fruit tree of India and China. It belongs to
family Rhamnaceae and is probably native to
India. Ber is also known as Chinese date or

Ber (Zizyphus mauritiana Lamk.) is an ancient
fruit tree of India and China. It belongs to
family Rhamnaceae and is probably native to
India. Ber is also known as Chinese date or
The present study was conducted with objective to know the effect of different pruning intensity and plant growth regulators on yield and quality of Gola cultivar. The present was comprised four different pruning intensity of previous season growth viz., $\mathrm{P}_{0}-$ no pruning, $\mathrm{P}_{1^{-}} 25 \%$ pruning, $\mathrm{P}_{2^{-}} 50 \%$ pruning, $\mathrm{P}_{3^{-}} 75 \%$ pruning and plant growth regulators viz., $\mathrm{C}_{0^{-}}$ control, $\mathrm{C}_{1^{-}}-\mathrm{GA}_{3} @ 10 \mathrm{ppm}$ and $\mathrm{C}_{2}$ - NAA @10 ppm. Significantly higher fruit weight $(23.69 \mathrm{~g})$ has been recorded with $75 \%$ pruning intensity + NAA $10 \mathrm{ppm}$ followed by $75 \%$ pruning intensity $+\mathrm{GA}_{3} 10 \mathrm{ppm}$ and least being in control. The highest fruit length, volume and width has been measured with $75 \%$ pruning intensity + NAA $10 \mathrm{ppm}$ and lowest were in control. The maximum fruit yield $(110.54 \mathrm{~kg} / \mathrm{plant})$ has been achieved by employing $50 \%$ severity of pruning with NAA $10 \mathrm{ppm}$ which found significantly superior over $25 \%$ pruning intensity+ NAA $10 \mathrm{ppm}$ and control. The highest severity of pruning (75\%) has been adjudged as supra-optimal level of pruning severity (negative effect) in increasing fruit yield. Significantly higher total soluble solid has been analyzed in fruits with $50 \%$ pruning intensity + NAA $10 \mathrm{ppm}$ followed by $50 \%$ pruning intensity $+\mathrm{GA}_{3} 10$ ppm and lowest noted in control, while pulp : stone ratio was significantly by various pruning intensities and plant growth regulators and recorded maximum in $75 \%$ pruning + 10 ppm NAA followed by $75 \%$ pruning $+\mathrm{GA}_{3}$. The maximum vitamin $\mathrm{C}$ content in fruits have been analyzed by $50 \%$ severity of pruning + NAA $10 \mathrm{ppm}$ followed by $50 \%$ pruning intensity $+\mathrm{GA}_{3} 10 \mathrm{ppm}$ with value was observed significant, while acidity of fruits were significant. The highest TSS : Acid ratio, reducing and non-reducing sugar and total sugar of fruits have been analyzed by $50 \%$ pruning intensity + NAA $10 \mathrm{ppm}$ and lowest one in control but variations were found significant in above all biochemical parameters.
Chinese fig or plum and commonly considered as "poor man's fruit". Ber is an important minor fruit of India which is reported to be grown in other countries like Iran, Syria, Australia, USA, France, certain parts of Italy, Spain and Africa. It is also reported that the 
Indian ber is an important fruit crop grown in tropical, sub tropical and arid regions of the world. It can be grown even on marginal soils and under various kinds of waste land situations such as sodic soil, saline soil, ravines, arid and semi-arid regions including plateau area of Bundelkhand and Southern India. Although (Zizyphus mauritianaLamk.) is now widely distributed and has become naturalized in tropical Africa, Burma, Jamaica, Iran, Srilanka and Syria, yet it is commercially important in India and China only. In Indiaber is widely cultivated in Punjab, Haryana, Uttar Pradesh, Rajasthan, Gujarat, Maharasthra, Andhra Pradesh, Bihar and Assam. The per capita consumption of ber is lowest in India. In certain areas, it is substitute of mango and citrus cultivation with more profitable than growing of cereals.

It can grow at altitude of 100 meter above sea level. However, it requires less care, even in neglected condition, it produces sufficient fruits. In view of the gaining popularity, area under this fruit is being increased gradually day by day. In Uttar Pradesh, ber orchards are found around Varanasi, Aligarh, Faizabad, Agra and Raibarely districts.

The ber cultivation is expanding because of its hardy nature to withstand vagaries of nature and the commercial yield potential. India annually produces around 37,97,606 MT ber fruits from an area of 61,279 ha (Bose et al., 2002). Fruits of ber commonly used in Indian house hold as fresh as well as dehydrated for later use.

At present, nearly $90 \%$ of its production is consumed as fresh fruit. The ber is a vigorous growing, small, spreading tree with almost vine like drooping branches. The species is evergreen and leaves are densely tomentose on their under surface. The fruits are round to oval and greenish yellow to reddish brown in color.

\section{Materials and Methods}

In the present study, 27 years old plants of ber cv. Gola having uniform vigour and productivity were selected as experimental material to find out effect of pruning intensity and plant growth regulator on plant growth, fruit yield and quality of fruits. The present investigation was carried out at the main experimental station, Department of Horticulture, N.D.U.A.\&T, Narendra Nagar (Kumarganj), Faizabad (U.P.) during the year 2015-2016. The experiment was laid out in Factorial Randomized Block Design with 12 treatments and 3 replications.

\section{Experimental details}

The details of experimental plan employed in present investigation were as follows:

Pruning intensity : 4

$\mathrm{P}_{0} \quad$ : No pruning of previous season growth

$\mathrm{P}_{1} \quad$ : $25 \%$ pruning of previous season growth

$\mathrm{P}_{2} \quad: \quad 50 \%$ pruning of previous season growth

$\mathrm{P}_{3} \quad: \quad 75 \%$ pruning of previous season growth

Plant Growth Regulator and Water:

$\mathrm{C}_{0}$ : Water spray (control)

$\mathrm{C}_{1}: \mathrm{GA}_{3}-10 \mathrm{ppm}$

$\mathrm{C}_{2}:$ NAA- $10 \mathrm{ppm}$

Total No. of treatments: 12

Experimental design : Factorial R.B.D.

(Randomized Block Design)

Replication : 3

Plant unit : 1

Total number of plants in experiment: 36

Time of pruning $\quad: \quad 3^{\text {rd }}$ week of May 
The pruning was done on one year old shoots in the $3^{\text {rd }}$ week of May with the help of secateurs.

\section{Method of preparation of solution of plant growth regulators}

The solutions were prepared as per concentrations of plant growth regulators $\left(\mathrm{GA}_{3}\right.$ and NAA). The required quantity of chemicals was weighed and dissolves in distilled water and absolute alcohol in measuring cylinder respectively. The dissolved solution was diluted and volume made up to 10 liters in plastic buckets as per required quantity of solutions.

\section{Results and Discussion}

Significantly higher fruit weight (23.69 gm) was recorded with application of $75 \%$ pruning intensity +10 ppm NAA as compared to $75 \%$ pruning intensity $+10 \mathrm{ppm} \mathrm{GA}_{3}$ and control, which may be due to higher nutrients availability to the fruits (Table 1). The similar results are reported by earlier workers Bajwa and Sarowa (1977),Gupta and Singh (1977), Singh and Bal (2008) and Singh et al., (2007). They advocated that maximum fruit weight was obtained with $8^{\text {th }}$ bud retention when pruning employed in ber fruit crop with application of $\mathrm{GA}_{3}$.

There was non-significantly higher fruit length $(3.89 \mathrm{~cm})$ has been measured with $75 \%$ pruning intensity +10 ppm NAA as compared to $75 \%$ pruning intensity $+10 \mathrm{ppm} \mathrm{GA}_{3}$ and unpruned shoot (control), whereas fruit width increased non-significantly with employing various pruning intensities and plant growth regulators (Table 2). The present findings is in conformity to Singh et al., (2004) who reported that maximum length and width achieved when ber plant pruned at $8^{\text {th }}$ bud level and Kale et al., (2000) reported that foliar spray with $\mathrm{GA}_{3}$ and NAA $10 \mathrm{ppm}$ and 20ppm increased fruit size in ber.

There was no significant variation observed in terms of fruit volume by applying various pruning intensities along with plant growth regulators. However, the maximum fruit volume $\left(23.17 \mathrm{~cm}^{3}\right)$ was measured with $75 \%$ pruning intensity with 10 ppm NAA, followed by $75 \%$ pruning with $10 \mathrm{ppm} \mathrm{GA}_{3}$ (Table 3 ).

Perusal of table 4 revealed that the maximum fruit yield per tree $(110.54 \mathrm{~kg})$ has been achieved by employing moderate pruning (50\% pruning intensity) +10 ppm $\mathrm{GA}_{3}$ which found significantly superior over $50 \%$ pruning intensity+ $10 \mathrm{ppm}$ NAA and control. Significantly higher fruit yield per tree might be due to increased percentage of both setting and retention of fruits, highest number of fruits per tree, fruit weight, fruit length and width with the help of $50 \%$ pruning intensity $10 \mathrm{ppm} \mathrm{GA}_{3}$ i.e. all these yield attributing characters paved the way for significant improvement in fruit yield per tree of ber. Another scientific explanation for significantly increasing yield with moderate pruning (50\% pruning intensity) may be because of more open tree canopy with wider leaf area resulted allowing more light penetration that led assimilation of more photosynthesis materials and also less competition for the growth of individual fruit as compared to unpruned tree under optimum time of pruning $\left(3^{\text {rd }}\right.$ week of May) condition. The present finding is in close agreement with earlier scientists viz.,Hiwaleand Singh(2004); Awasthi and Mishra (1969) and Khanand Syamal (2004), who reported that medium pruning of $50 \%$ produced higher yield in ber fruit. As pruning intensity advanced i.e. at sever pruning (75\% pruning intensity) yield was reduced. The reduction in yield with severe pruning $(75 \%)$ might be due to admitted fact that reduction in number of bearing shoots. 
Table.1 Effect of pruning intensity and plant growth regulators on fruit weight $(\mathrm{g})$ of ber fruit cv. Gola

\begin{tabular}{|c|c|c|c|c|c|}
\hline \multirow[t]{2}{*}{ Plant Growth Regulators } & \multicolumn{5}{|c|}{ Pruning intensity } \\
\hline & $0 \%\left(\mathbf{P}_{0}\right)$ & $\begin{array}{c}25 \% \\
\left(\mathbf{P}_{1}\right)\end{array}$ & $\begin{array}{c}50 \% \\
\left(\mathbf{P}_{2}\right)\end{array}$ & $\begin{array}{c}75 \% \\
\left(P_{3}\right)\end{array}$ & Mean \\
\hline $\mathrm{C}_{0}$ (Water) & 17.90 & 20.06 & 20.73 & 21.69 & 20.10 \\
\hline $\mathrm{C}_{1}\left(\mathrm{GA}_{3} 10 \mathrm{ppm}\right)$ & 18.73 & 20.90 & 21.99 & 22.66 & 21.07 \\
\hline $\mathrm{C}_{2}$ (NAA $\left.10 \mathrm{ppm}\right)$ & 19.61 & 21.43 & 22.57 & 23.69 & 21.83 \\
\hline \multirow[t]{2}{*}{ Mean } & 18.23 & 20.48 & 21.36 & 22.18 & 20.58 \\
\hline & A & B & $A \times B$ & & \\
\hline SEm \pm & 0.074 & 0.064 & 0.128 & & \\
\hline $\mathrm{CD}$ at $5 \%$ & 0.214 & 0.185 & NS & & \\
\hline
\end{tabular}

Table.2 Effect of pruning intensity and plant growth regulators on fruit length of ber fruit cv. Gola

\begin{tabular}{|c|c|c|c|c|c|}
\hline \multirow[t]{2}{*}{ Plant Growth Regulators } & \multicolumn{5}{|c|}{ Pruning intensity } \\
\hline & $\mathbf{0} \%\left(\mathbf{P}_{0}\right)$ & $\begin{array}{c}25 \% \\
\left(\mathbf{P}_{1}\right)\end{array}$ & $\begin{array}{c}\mathbf{5 0} \% \\
\left(\mathbf{P}_{2}\right)\end{array}$ & $\begin{array}{c}75 \% \\
\left(\mathbf{P}_{3}\right)\end{array}$ & Mean \\
\hline $\mathrm{C}_{0}$ (Water) & 3.40 & 3.62 & 3.64 & 3.69 & 3.59 \\
\hline $\mathrm{C}_{1}\left(\mathrm{GA}_{3} 10 \mathrm{ppm}\right)$ & 3.55 & 3.66 & 3.79 & 3.87 & 3.72 \\
\hline $\mathrm{C}_{2}$ (NAA $\left.10 \mathrm{ppm}\right)$ & 3.61 & 3.68 & 3.80 & 3.89 & 3.75 \\
\hline \multirow[t]{2}{*}{ Mean } & 3.48 & 3.64 & 3.72 & 3.78 & 3.65 \\
\hline & A & B & A $x$ B & & \\
\hline SEm \pm & NS & NS & NS & & \\
\hline $\mathrm{CD}$ at $5 \%$ & NS & NS & NS & & \\
\hline
\end{tabular}

Table.3 Effect of pruning intensity and Plant growth regulators on fruit volume $(\mathrm{cm} 3)$ of ber fruit cv. Gola

\begin{tabular}{|l|c|c|c|c|c|}
\hline Plant Growth Regulators & \multicolumn{5}{|c|}{ Pruning intensity } \\
\cline { 2 - 5 } & $\mathbf{0 \%}\left(\mathbf{P}_{\mathbf{0}}\right)$ & $\mathbf{2 5 \%}$ & $\mathbf{5 0} \%$ & $\mathbf{7 5} \%$ & Mean \\
& & $\left(\mathbf{P}_{\mathbf{1}}\right)$ & $\left.\mathbf{( P}_{\mathbf{2}}\right)$ & $\left(\mathbf{P}_{\mathbf{3}}\right)$ & \\
\hline $\mathrm{C}_{0}$ (Water) & 18.43 & 20.55 & 20.98 & 22.16 & 20.53 \\
\hline $\mathrm{C}_{1}\left(\mathrm{GA}_{3} 10 \mathrm{ppm}\right)$ & 19.82 & 21.45 & 22.25 & 22.90 & 21.61 \\
\hline $\mathrm{C}_{2}$ (NAA 10 ppm) & 20.53 & 21.61 & 22.32 & 23.17 & 21.91 \\
\hline Mean & 19.13 & 21.00 & 21.62 & 22.53 & 21.07 \\
\hline & $\mathrm{A}$ & $\mathrm{B}$ & $\mathrm{A} \times \mathrm{B}$ & & \\
\hline $\mathrm{SEm} \pm$ & 0.140 & 0.121 & 0.243 & & \\
\hline $\mathrm{CD}$ at 5\% & 0.406 & 0.351 & $\mathrm{NS}$ & & \\
\hline
\end{tabular}


Table.4 Effect of pruning intensity and Plant growth regulators fruit yield (kg/plant) of ber fruit cv. Gola

\begin{tabular}{|l|c|c|c|c|c|}
\hline Plant Growth Regulators & \multicolumn{5}{|c|}{ Pruning intensity } \\
\cline { 2 - 6 } & $\left.\mathbf{0} \% \mathbf{( P}_{\mathbf{0}}\right)$ & $\mathbf{2 5} \%$ & $\mathbf{5 0} \%$ & $\mathbf{7 5} \%$ & Mean \\
& & $\left(\mathbf{P}_{\mathbf{1}}\right)$ & $\left(\mathbf{P}_{\mathbf{2}}\right)$ & $\mathbf{( \mathbf { P } _ { 3 } )}$ & \\
\hline $\mathrm{C}_{0}($ Water$)$ & 64.87 & 87.35 & 105.30 & 104.45 & 90.49 \\
\hline $\mathrm{C}_{1}\left(\mathrm{GA}_{3} 10 \mathrm{ppm}\right)$ & 66.75 & 88.91 & 110.54 & 109.33 & 93.88 \\
\hline $\mathrm{C}_{2}(\mathrm{NAA} 10 \mathrm{ppm})$ & 65.28 & 88.23 & 109.87 & 106.19 & 92.39 \\
\hline Mean & 65.81 & 88.13 & 107.92 & 106.89 & 92.19 \\
\hline & $\mathrm{A}$ & $\mathrm{B}$ & $\mathrm{A} \times \mathrm{B}$ & & \\
\hline SEm \pm & 0.088 & 0.077 & 0.153 & & \\
\hline $\mathrm{CD}$ at 5\% & 0.256 & 0.222 & 0.443 & & \\
\hline
\end{tabular}

Table.5 Effect of pruning intensity and plant growth regulators on pulp: stone ratio of ber fruit cv. Gola

\begin{tabular}{|l|c|c|c|c|c|}
\hline Plant Growth Regulators & \multicolumn{5}{|c|}{ Pruning intensity } \\
\cline { 2 - 6 } & $\left.\mathbf{0} \% \mathbf{( P}_{\mathbf{0}}\right)$ & $\mathbf{2 5} \mathbf{\%}$ & $\mathbf{5 0} \%$ & $\mathbf{7 5} \%$ & Mean \\
\hline $\mathrm{C}_{0}$ (Water) & & $\left(\mathbf{P}_{\mathbf{1}}\right)$ & $\left(\mathbf{P}_{\mathbf{2}}\right)$ & $\left(\mathbf{P}_{\mathbf{3}}\right)$ & \\
\hline $\mathrm{C}_{1}\left(\mathrm{GA}_{3}\right.$ 10 ppm) & 10.07 & 11.07 & 11.21 & 11.31 & 10.91 \\
\hline $\mathrm{C}_{2}$ (NAA 10 ppm) & 10.50 & 11.24 & 11.36 & 11.40 & 11.13 \\
\hline Mean & 10.92 & 11.28 & 11.39 & 11.50 & 11.27 \\
\hline & 10.29 & 11.16 & 11.28 & 11.35 & 11.02 \\
\hline SEm \pm & $\mathrm{A}$ & $\mathrm{B}$ & $\mathrm{A} \times \mathrm{B}$ & & \\
\hline $\mathrm{CD}$ at 5\% & 0.034 & 0.030 & 0.059 & & \\
\hline
\end{tabular}

Table.6 Effect of pruning intensity and plant growth regulators on TSS (0Brix) of ber fruit cv. Gola

\begin{tabular}{|c|c|c|c|c|c|}
\hline \multirow[t]{2}{*}{ Plant Growth Regulators } & \multicolumn{5}{|c|}{ Pruning intensity } \\
\hline & $0 \%\left(\mathbf{P}_{0}\right)$ & $\begin{array}{c}25 \% \\
\left(P_{1}\right)\end{array}$ & $\begin{array}{c}50 \% \\
\left(\mathbf{P}_{2}\right)\end{array}$ & $\begin{array}{c}75 \% \\
\left(\mathbf{P}_{3}\right)\end{array}$ & Mean \\
\hline $\mathrm{C}_{0}$ (Water) & 13.25 & 13.38 & 13.4 & 13.83 & 13.50 \\
\hline $\mathrm{C}_{1}\left(\mathrm{GA}_{3} 10 \mathrm{ppm}\right)$ & 14.10 & 14.28 & 14.66 & 14.46 & 14.38 \\
\hline $\mathrm{C}_{2}$ (NAA 10 ppm) & 14.25 & 14.36 & 14.80 & 14.57 & 14.50 \\
\hline Mean & 13.68 & 13.83 & 14.15 & 14.10 & 13.94 \\
\hline & A & B & $A \times B$ & & \\
\hline SEm \pm & 0.012 & 0.011 & 0.021 & & \\
\hline $\mathrm{CD}$ at $5 \%$ & 0.035 & 0.031 & 0.061 & & \\
\hline
\end{tabular}


Table.7 Effect of pruning intensity and plant growth regulators on acidity of ber fruit cv. Gola

\begin{tabular}{|c|c|c|c|c|c|}
\hline \multirow[t]{2}{*}{ Plant Growth Regulators } & \multicolumn{5}{|c|}{ Pruning intensity } \\
\hline & $\mathbf{0} \%\left(\mathbf{P}_{0}\right)$ & $\begin{array}{c}25 \% \\
\left(\mathbf{P}_{1}\right)\end{array}$ & $\begin{array}{c}50 \% \\
\left(\mathbf{P}_{2}\right)\end{array}$ & $\begin{array}{c}75 \% \\
\left(\mathrm{P}_{3}\right)\end{array}$ & Mean \\
\hline $\mathrm{C}_{0}$ (Water) & 0.30 & 0.32 & 0.34 & 0.35 & 0.33 \\
\hline $\mathrm{C}_{1}\left(\mathrm{GA}_{3} 10 \mathrm{ppm}\right)$ & 0.36 & 0.42 & 0.53 & 0.47 & 0.44 \\
\hline $\mathrm{C}_{2}$ (NAA $\left.10 \mathrm{ppm}\right)$ & 0.37 & 0.44 & 0.56 & 0.49 & 0.47 \\
\hline \multirow[t]{2}{*}{ Mean } & 0.33 & 0.37 & 0.44 & 0.41 & 0.39 \\
\hline & A & $\mathrm{B}$ & $\mathrm{A} \times \mathrm{B}$ & & \\
\hline SEm \pm & 0.008 & 0.007 & 0.014 & & \\
\hline $\mathrm{CD}$ at $5 \%$ & 0.024 & 0.021 & 0.041 & & \\
\hline
\end{tabular}

Table.8 Effect of pruning intensity and plant growth regulators on ascorbic acid (mg/100 g pulp) of ber fruit cv. Gola

\begin{tabular}{|c|c|c|c|c|c|}
\hline \multirow[t]{2}{*}{ Plant Growth Regulators } & \multicolumn{5}{|c|}{ Pruning intensity } \\
\hline & $0 \%\left(\mathbf{P}_{0}\right)$ & $\begin{array}{c}25 \% \\
\left(\mathbf{P}_{1}\right)\end{array}$ & $\begin{array}{c}50 \% \\
\left(\mathbf{P}_{2}\right)\end{array}$ & $\begin{array}{c}75 \% \\
\left(\mathbf{P}_{3}\right)\end{array}$ & Mean \\
\hline $\mathrm{C}_{0}$ (Water) & 40.50 & 40.58 & 40.61 & 41.60 & 40.82 \\
\hline $\mathrm{C}_{1}\left(\mathrm{GA}_{3} 10 \mathrm{ppm}\right)$ & 41.63 & 42.86 & 44.58 & 42.94 & 43.00 \\
\hline $\mathrm{C}_{2}$ (NAA $\left.10 \mathrm{ppm}\right)$ & 41.64 & 42.90 & 44.65 & 44.52 & 43.43 \\
\hline \multirow[t]{2}{*}{ Mean } & 41.07 & 41.72 & 42.60 & 42.27 & 41.91 \\
\hline & A & B & $A \times B$ & & \\
\hline SEm \pm & 0.009 & 0.007 & 0.015 & & \\
\hline $\mathrm{CD}$ at $5 \%$ & 0.025 & 0.022 & 0.043 & & \\
\hline
\end{tabular}

Table.9 Effect of pruning intensity and plant growth regulators on reducing sugar of ber fruit cv. Gola

\begin{tabular}{|c|c|c|c|c|c|}
\hline \multirow[t]{2}{*}{ Plant Growth Regulators } & \multicolumn{5}{|c|}{ Pruning intensity } \\
\hline & $\mathbf{0} \%\left(\mathbf{P}_{\mathbf{0}}\right)$ & $\begin{array}{c}25 \% \\
\left(\mathbf{P}_{1}\right)\end{array}$ & $\begin{array}{c}50 \% \\
\left(\mathbf{P}_{2}\right)\end{array}$ & $\begin{array}{c}75 \% \\
\left(\mathbf{P}_{3}\right)\end{array}$ & Mean \\
\hline $\mathrm{C}_{0}$ (Water) & 4.34 & 4.36 & 4.37 & 4.40 & 4.37 \\
\hline $\mathrm{C}_{1}\left(\mathrm{GA}_{3} 10 \mathrm{ppm}\right)$ & 4.42 & 4.49 & 4.57 & 4.53 & 4.50 \\
\hline $\mathrm{C}_{2}$ (NAA $\left.10 \mathrm{ppm}\right)$ & 4.47 & 4.51 & 4.62 & 4.55 & 4.54 \\
\hline \multirow[t]{2}{*}{ Mean } & 4.38 & 4.43 & 4.52 & 4.47 & 4.44 \\
\hline & A & B & $A \times B$ & & \\
\hline SEm \pm & 0.007 & 0.006 & 0.011 & & \\
\hline $\mathrm{CD}$ at $5 \%$ & 0.019 & 0.016 & 0.033 & & \\
\hline
\end{tabular}


Table.10 Effect of pruning intensity and plant growth regulators on non-reducing sugar (\%) of ber fruit cv. Gola

\begin{tabular}{|l|c|c|c|c|c|}
\hline Plant Growth Regulators & \multicolumn{5}{|c|}{ Pruning intensity } \\
\cline { 2 - 6 } & $\left.\mathbf{0} \% \mathbf{P}_{\mathbf{0}}\right)$ & $\mathbf{2 5} \%$ & $\mathbf{5 0} \%$ & $\mathbf{7 5} \%$ & Mean \\
& & $\left(\mathbf{P}_{\mathbf{1}}\right)$ & $\left(\mathbf{P}_{\mathbf{2}}\right)$ & $\left(\mathbf{P}_{\mathbf{3}}\right)$ & \\
\hline $\mathrm{C}_{0}($ Water$)$ & 2.55 & 2.58 & 2.61 & 2.62 & 2.59 \\
\hline $\mathrm{C}_{1}\left(\mathrm{GA}_{3} 10 \mathrm{ppm}\right)$ & 2.63 & 2.65 & 2.78 & 2.70 & 2.69 \\
\hline $\mathrm{C}_{2}(\mathrm{NAA} 10 \mathrm{ppm})$ & 2.64 & 2.67 & 2.80 & 2.75 & 2.72 \\
\hline Mean & 2.61 & 2.61 & 2.70 & 2.66 & 2.64 \\
\hline & $\mathrm{A}$ & $\mathrm{B}$ & $\mathrm{A} \times \mathrm{B}$ & & \\
\hline SEm \pm & 0.007 & 0.006 & 0.011 & & \\
\hline $\mathrm{CD}$ at 5\% & 0.019 & 0.016 & 0.033 & & \\
\hline
\end{tabular}

Table.11 Effect of pruning intensity and plant growth regulators on total sugars $(\%)$ of ber fruit cv. Gola

\begin{tabular}{|c|c|c|c|c|c|}
\hline \multirow[t]{2}{*}{ Plant Growth Regulators } & \multicolumn{5}{|c|}{ Pruning intensity } \\
\hline & $\mathbf{0} \%\left(\mathbf{P}_{0}\right)$ & $\begin{array}{c}25 \% \\
\left(\mathbf{P}_{1}\right)\end{array}$ & $\begin{array}{c}50 \% \\
\left(\mathbf{P}_{2}\right)\end{array}$ & $\begin{array}{c}75 \% \\
\left(\mathbf{P}_{3}\right)\end{array}$ & Mean \\
\hline $\mathrm{C}_{0}($ Water $)$ & 6.89 & 6.93 & 6.98 & 7.02 & 6.96 \\
\hline $\mathrm{C}_{1}\left(\mathrm{GA}_{3} 10 \mathrm{ppm}\right)$ & 7.05 & 7.14 & 7.35 & 7.23 & 7.19 \\
\hline $\mathrm{C}_{2}$ (NAA $\left.10 \mathrm{ppm}\right)$ & 7.11 & 7.17 & 7.42 & 7.30 & 7.25 \\
\hline \multirow[t]{2}{*}{ Mean } & 6.97 & 7.04 & 7.17 & 7.13 & 7.08 \\
\hline & A & B & $A \times B$ & & \\
\hline SEm \pm & 0.010 & 0.008 & 0.016 & & \\
\hline $\mathrm{CD}$ at $5 \%$ & 0.028 & 0.024 & 0.048 & & \\
\hline
\end{tabular}

The result is in accordance with Gupta and Singh (1977); Bajwa et al., (1986); and Gill and Bal (2006) who observed yield was decreased by severe pruning.

Effect of pruning intensity and plant growth regulators on fruit quality parameters

Various quality parameters viz., TSS, Vitamin $\mathrm{C}$, Reducing and non-reducing sugar etc. have been greatly influenced by employing various pruning intensities and plant growth regulators in ber fruit crop.

The highest pulp:stone ratio (11.50) was measured with $75 \%$ pruning intensity+ 10 ppm NAA as compared to other treatments having significant variation (Table 5). Similar finding was also observed by Singh et al.,(1978) and Kundu et al., (1995).

Significantly higher TSS $(14.80 \%)$ has been analysed in the fruits that produced with $50 \%$ pruning intensity $+10 \mathrm{ppm}$ NAA as compared to other treatments (Table 6). The higher TSS achieved due to $50 \%$ pruning intensity might be owing to more photosynthetic material (CHO-rich) and nutrients stored in the pruned shoot (50\% pruning intensity) than unpruned shoot. The present findings is in close agreement with earlier workers Gupta and Singh (1977), Singh et al., (1978), Hiwale and Raturi (1983), Bajwa et al.,(1986),Yadav and 
Godara (1987). Employing various pruning intensities that influenced analysis of fruits it terms of acidity (\%) is in significant manner, While Vitamin C (44.65 mg/100 gm pulp) was analyzed in fruit that produced through $50 \%$ pruning intensity +10 ppm NAA. Acidity was not influenced by present findings was also in agreement of Awasthi and Mishra (1969). Higher Vitamin C analyzed due to moderate pruning $(50 \%)+10$ ppm NAA in present findings that are in conformity to earlier workers Singh et al., (1978), Syamal and Rajput (1989) and Yadav (1998). The maximum TSS: Acidity ratio was analysed with $50 \%$ pruning intensity $+10 \mathrm{ppm}$ NAA as compared to $50 \%$ pruning intensity +10 ppm $\mathrm{GA}_{3}$ and control which having significant variation. Moreover, pruning intensity at $50 \%$ and $75 \%$ both were found at part in affecting TSS: Acidity ratio (Table 7$11)$.

The highest reducing sugar and non-reducing sugar and total sugar have been analyzed in the fruits that produced with moderate pruning $(50 \%$ pruning intensity) $+10 \mathrm{ppm}$ NAA as compared to $50 \%$ pruning intensity +10 ppm $\mathrm{GA}_{3}$ and unpruned tree (control) but differences were found non-significant. Higher reducing sugar and non-reducing sugar and total sugar achieved with help of $50 \%$ pruning intensity $+10 \mathrm{ppm}$ NAA. Beneficial effect of pruning and plant growth regulators on these biochemical characters of fruits were also obtained by Bajwaet al., (1988), Shymal and Rajput (1989), Sandhu et al., (1992) and Yadav et al., (2005) in ber fruit crop and Singh (2005) in Aonla fruit crops and Singh et al., (1989) in ber fruit and Dahiwal and Sandhu (1982) in ber fruit cv. Umran.

\section{References}

Awasthi, A.M. and Mishra, R. (1969). Effect of pruning on subsequent vegetation growth, fruit set, fruit drop and quality in ber (Zizyphus mauritiana Lamk.) cultivars. Punjab Hort. J., 9 (1-2): 5460.

Bajawa, G.S.; Shandhu, H.S. and Bal, J.S. (1986). Pruning inber (Zizyphus mauritana Lamk.)-A Review. Indian. J.Hort. Sci., 43 (3 \& 4): 203-206.

Bajawa, M.S. and Sarowa, P.S. (1977). Pruning in ber (Zizyphus mauritana Lamk.)-A Review. Punjab Hort. J. 17: 52-53.

Dhaliwal, H.S. and Sandhu, I.P.S. (1982). Effect of pruning on vegetative growth, flowering and fruit set in ber (Zizyphus mauritiana Lamk.) cv. Umran. Haryana J. Hort. Sci.11 (3-4): 208-212.

Gill, K.S. and Bal, J.S. (2006). Influence of pruning severity and time on yield and fruit quality of ber (Zizyphus mauritiana Lamk.) cv. Umran. Indian J. Hort. 63(2): 162-165.

Gupta, M.R. and Singh, S. (1977). Effect of prunig on growth, yield and fruit quality in ber. Punjab Hort. J., 17 (1-2): 54-57.

Gupta, M.R. and Singh, S. (1977). Effect of prunig on growth, yield and fruit quality in ber. Punjab Hort. J., 17(1-2): 54-57.

Hiwale, S.S. and Raturi, G.B. (1993). Effect of pruning severity on growth, yield and quality of ber. prog. Hort. 25 (3/4): 161163.

Kale, V.S.; V.H. Dod, R.M. Adapawar and S.G. Bharad (2000). Effect of plant growth regulators on fruit charecters and quality of ber (Zizyphus mauritiana Lamk.). Crop Research Hissar20 (2): 327-333.

Khan, M. and Syamal, M.M. (2004). Effect of pruning intensity on flowering and fruiting of Kagzi lime (Citrus aurantifolia Swingle) Indian J. Hort.61 (2): 171-172.

Kundu, S.S. (1994). Pruning in ber (Zizyphus mauritiana Lamk.)-A Review. Annu. Arid Zone 3 (1): 49-52. 
Sandhu, A.S. (1992). Pruning in ber (Zizyphus mauritianaLamk.)-A Review. Hryana J. Hort. Sci.21: 1-5.

Singh, A.K.; Shukla, P.K. and Singh, K. (1989). Effect of boron, zinc and NAA on the chemical composition and metabolism of ber (Zizyphus mauritiana Lamk.) fruit. Haryana J. Hort. Sci.,18 (1-2): 23-28.

Singh, H. (2004). Pruning in ber (Zizyphus mauritiana Lamk.)-A Review. Indian J. Hort. 61 (3): 259-260.

Singh, R. and Bal, J.S. (2008). Pruning in ber (Zizyphus mauritiana Lamk.) Agric. Rew., 29 (1): 61-67.

Singh, S.K. (2005) "Studies on pruning behaviour in Aonla (Emblica officinalis Garten.) cv. NA-7" NDUAT thesis
Kumarganj, Faizabad, (U.P).

Syamal, M.M. and Rajput, C.B.S. (1989). Effect of pruning on growth, flowering and fruit quality of ber (Zizyphus mauritiana Lamk.). cv. Banarasi karaka. Indian J. Hort., 46 (3): 364-367.

Yadav, P.K. (1998). Note on yield and quality parameters of guava as influenced by foliar application of nutrients and plant growth regulators. Current Agri., 22 (12): $117-119$.

Yadava, L.S. and Godra, N.R. (1987). Effect of planting distance and severity of pruning on physico-chemical characteristics of ber (Zizyphus mauritiana Lamk.). cv. Umran. Haryana J. Hort. Sci. 16 (1-2): 45-51.

\section{How to cite this article:}

Sneha Singh, Bhanu Pratap, Sachi Gupta, Dheeraj Yadav, Abhinav Kumar, Swosti Debapriya, Behera and Madhusoodan Singh. 2019. Assess the Effect of Pruning and Plant Growth Regulators on Yield and Quality of Ber Fruit. Int.J.Curr.Microbiol.App.Sci. 8(01): 539-547. doi: https://doi.org/10.20546/ijcmas.2019.801.060 